\title{
Reaction of estuarine ecosystems to effluent from pulp and paper industry
}

\author{
N. J. Poole ${ }^{1}$, R. J. Parkes ${ }^{1} \&$ D. J. Wildish ${ }^{2}$ \\ 1 Department of Microbiology, University of Aberdeen; Aberdeen, Scotland, U.K., \\ and \\ 2 Department of the Environment, Biological Station; St. Andrews, N.B., Canada
}

\begin{abstract}
A major problem associated with the discharge of pulp or paper-mill effluent into shallow estuarine ecosystems, such as the upper L'Etang in Canada or the Don in Scotland, is the development of anoxic conditions in water column and sediment. The effluent modifies the balance, within the ecosystem, between the supply of, and demand for, oxygen. The lignosulphonate component of pulp-mill effluent blocks the transmission of light energy to photosynthetic green plants. The oxygen demand is increased by the microbial degration of the additional organic matter in water and sediment. The addition of cellulosic pulp fibre to the sediment also results in an increase in the concentration of their metabolic by-product, sulphide. The oxidation of sulphide exerts an additional oxygen demand on the system, which is an important factor in the development and maintenance of anoxic conditions. It is suggested that temperature is an important factor in controlling the release of sulphide from the sediment into the overlying water and in modifying the toxicity of sulphide towards the bacterial populations and, therefore, the capacity of the ecosystem to cope with the effluent.
\end{abstract}

\section{INTRODUCTION}

Water plays an important role in the location of a pulp and/or paper mill. Not only is a good supply of water necessary for the manufacturing process, but the water course is also used as a receiver of the large volumes of effluent, which are a characteristic by-product of this industry. This paper considers the reaction of the shallow estuarine ecosystem to the discharge of this effluent and, in particular, those factors which lead to the development of anoxic conditions within the water column and sediment. The discussion will be developed by reference to work on two ecosystems, the upper L'Etang in Canada and the Aberdeenshire Don in Scotland.

\section{THE SYSTEMS}

\section{'The Upper L'Etang}

The L'Etang is a marine tidal inlet extending $14 \mathrm{~km}$ landwards from the Bay of Fundy near Black's Harbour, New Brunswick, Canada. The inlet is divided into 
an upper (landward) and a lower portion by a $200 \mathrm{~m}$ long road-carrying causeway, approximately $2 \mathrm{~km}$ from the head. The surface areas of the upper and lower portions are $1.35 \mathrm{~km}^{2}$ and $28.37 \mathrm{~km}^{2}$, respectively. To permit the exchange of water between the upper and lower L'Etang there are, within the causeway, four corrugated steel culverts, each with a diameter of $1.6 \mathrm{~m}$. One culvert is $1.7 \mathrm{~m}$ below low water, while the remainder are at a higher elevation and permit water to enter the upper L'Etang on the flood tide. The effect of the causeway has been to impound the waters of the upper L'Etang. 'The tidal amplitudes of the upper and lower L'Etang, at either side of the causeway, are $0.1 \mathrm{~m}$ and 6.9 to $8.5 \mathrm{~m}$, respectively.

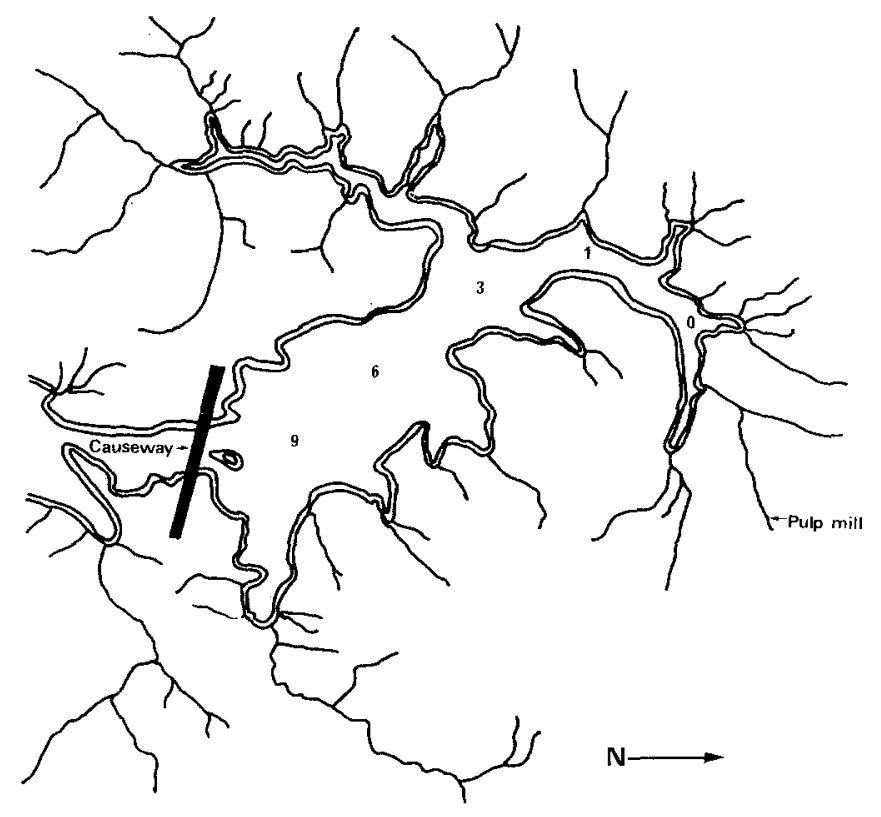

Fig. 1: Upper L'Etang sampling stations

During the summer months a distinct halocline exists, between the causeway and Station 1 (Fig. 1), at a depth of $1.5 \mathrm{~m}$ (Kristmanson et al., 1976). On a flood tide oxygenated seawater enters the upper L'Etang via the causeway and flows under the less dense freshwater. This process, coupled with the freshwater input and windgenerated movements causes a surface flow towards the causeway. Some of the saltwater in the bottom layer eventually mixes with the surface layer in the regions of Stations 1 and 0 , while the remainder drains back into the lower L'Etang on the ebb tide.

In 1971 a pulpmill, situated near Lake Utopia, began to discharge its effluent into the brook which empties into the north-eastern arm of the upper L'Etang. This mill produces pulp from hardwoods by the sodium sulphite process. For every tonne of pulp produced by this process about one tonne of soluble products go to waste; this effluent contains lignosulphonates, various sugars, sugar acids, resins and insoluble 
pulp fibre. The effluent discharged into the upper L'Etang receives minimal chemical and microbiological treatment.

The upper L'Etang is now an anoxic mass of water with extensive deposits of pulp fibre on the bed. During the summer months there is continuous bubbling of the water in the upper reaches as hydrogen sulphide is released into the atmosphere. The high atmospheric concentration of hydrogen sulphide in the environs of the upper L'Etang causes considerable public indignation.

\section{The Aberdeenshire Don}

The Don is a shallow estuary (area $0.17 \mathrm{~km}^{2}$ ) with a distinct halocline from just above Station B to the mouth (Fig. 2); only during the summer months, when there is reduced freshwater input, does saltwater reach Station A. Due to the reverse gradient of the estuary bed, and the northward movement of the mouth, with the development of a sand-spit, there is limited tidal flushing action. Prior to the river entering

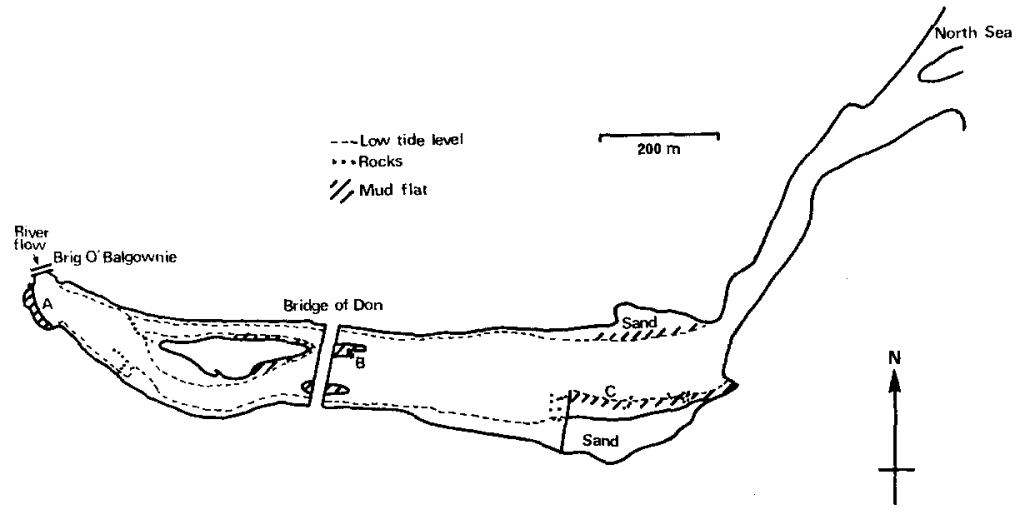

Fig. 2: Aberdeenshire Don sampling stations

the estuary it receives the effluent from two large paper mills. Paper mill effluent contains in addition to the cellulosic pulp fibre, size and filler e.g. china clay and $\mathrm{BaSO}_{4}$. Though this effluent is well treated, there is none the less a marked production of hydrogen sulpide in the estuary during the summer months and this causes considerable environmental problems.

\section{EFFECT OF PULP MILL EFFLUENT ON T'HE UPPER L'ETANG}

This shallow estuarine ecosystem consists of three linked subsystems (Poole et al., 1976a): (1) The surface waters above the halocline, (2) the bottom layer of water, and (3) the sediment.

The soluble lignosulphonate (Fig. 3) and sugar (Fig. 4) components of the pulp 
mill effluent are restricted mainly to the surface layer of the water column, while the visual appearance of, and high volatile solids in, the sediment (Fig. 5) indicates that the pulp fibre rapidly settles out. The concentration of the soluble components decreases in the seawards direction due to dilution and microbial activity.

The organic matter imported into the ecosystem modifies the flow of energy and the balance between the supply and demand for oxygen. Oxygen can enter the surface waters via the freshwater input, diffusion from the atmosphere or as a product of green-plant photosynthesis, while seawater passing through the causeway on the flood tide supplies the bottom layer of the water column with oxygen.
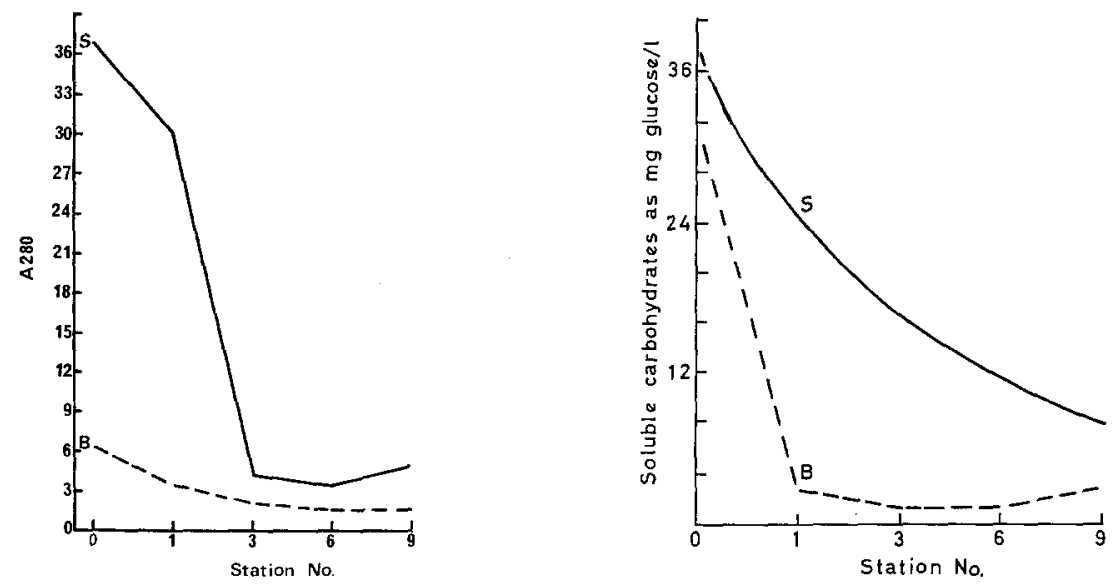

Fig. 3: Distribution in upper L'Etang of Lignosulphonate, as determined by absorbance at $280 \mathrm{~nm}$ (Wildish et al., 1976); $\mathrm{S}: 5 \mathrm{~cm}$ from surface; B: $30 \mathrm{~cm}$ above sediment

Fig. 4: Distribution in upper L'Etang of soluble carbohydrates, as determined by a modified phenol-sulphuric acid method (Poole et al., 1976a). S: $5 \mathrm{~cm}$ from surface; B: $30 \mathrm{~cm}$ above sediment

In "normal" estuarine and marine sediments there is an upper aerobic zone above an anoxic zone (Ramm \& Bella, 1974). Oxygen is supplied to the upper zone of the sediment by diffusion from and mixing with the overlying water. The degree of mixing is dependant upon a number of factors e.g. particle size and the activities of burrowing organisms. Pulp fibre, however, alters the physical characteristics of the sediment; Pearson \& Rosenburg (1976) have also shown that as pulp mill pollution develops in fjord systems, physically smaller and surface dwelling animals predominate, hence decreasing the degree of mixing.

The sugars in the surface layer of the water column and the cellulosic fibres within the sediment are utilized by the microbial community as a source of carbon and energy; this results in a high oxygen demand on the system. This demand should not be confused with that measured by the five day Biochemical Oxygen Demand (B.O.D.) method, since cellulose is only slowly degraded by micro-organisms; its oxygen demand, as determined by the B.O.D. method approaches zero. In the upper L'Etang the transmission of light energy to the aquatic plants, in the seawater below the 
halocline, would be blocked by the presence of lignosulphonates in the water column (Parker \& Sibert, 1973, 1976); hence, there is no production of oxygen by photosynthesis. As a result of these factors, the demand for oxygen in the upper L'Etang far exceeds the supply. In the summer months, both the sediment and water column are anoxic. Even in the bottom layer of water, where there is little additional organic
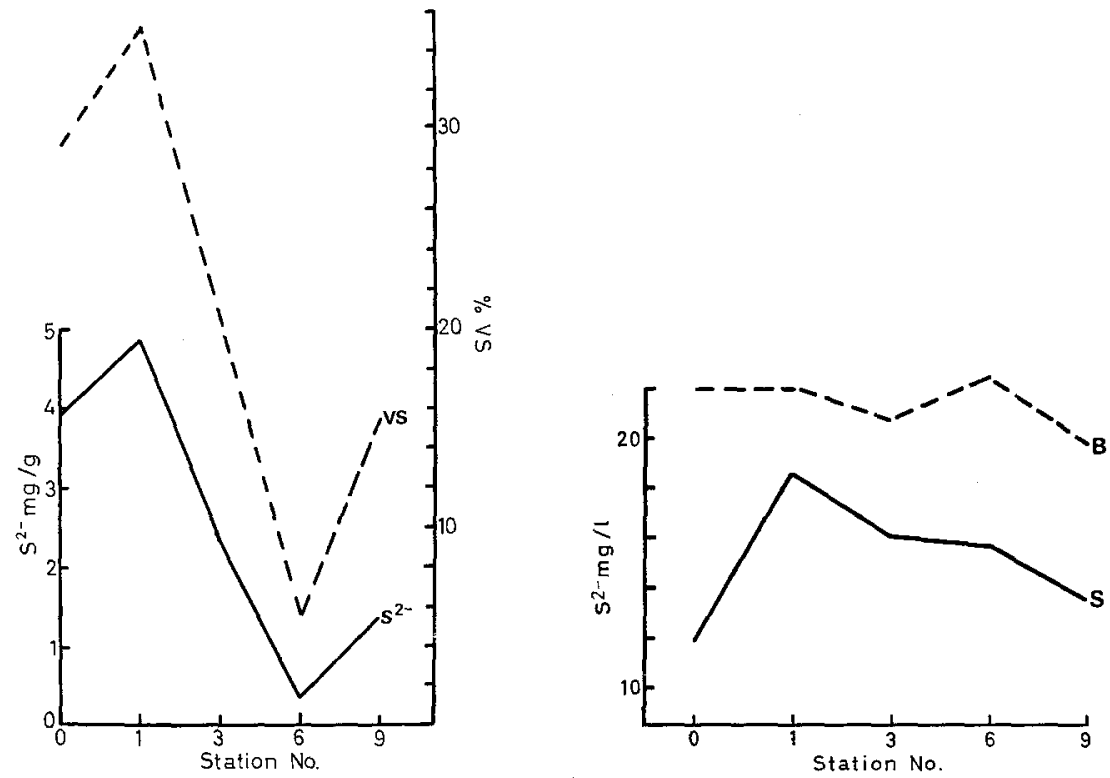

Fig. 5: Sulphide concentration, as determined by an ion-selective electrode, and percentage volatile solids in the sediments of upper L'Etang

Fig. 6: Distribution in upper L'Etang of sulphide, as determined by an ion-selective electrode. $S: 5 \mathrm{~cm}$ from surface; $\mathrm{B}: 30 \mathrm{~cm}$ above sediment

matter and therefore little increase in microbial activity, there is no oxygen. ATP measurements are a useful measure of biotic activity (Holm-Hansen, 1973); the average ATP concentration of the surface layer was $3.14 \mu \mathrm{g} \mathrm{1-1,} \mathrm{while} \mathrm{in} \mathrm{the} \mathrm{bottom} \mathrm{layer}$ it was only $0.32 \mu \mathrm{g} \mathrm{t}^{-1}$.

In the absence of oxygen the microbial community changes to include bacterial populations which can use fermentative metabolic pathways or other electron acceptors e.g. nitrate, sulphate and carbonate. Sulphate is one of the major anions in seawater, therefore bacterial sulphate reduction is often an important reaction in marine systems. The sulphate-reducing bacteria are active in the sediments of the upper L'Etang and their metabolic by-product, sulphide diffuses from the sediment into the overlying water column and atmosphere. Sulphides form insoluble compounds with heavy metals, in particular iron, and its concentration in the sediment will remain at a low level when available iron is present; the reactions between iron and sulphides, which are not well understood, have been reviewed by Goldhaber \& Kaplan (1974). When sulphide is released into the water column, its oxidation exerts a chemical oxygen 
demand on the system. The half life of sulphide in $0.2 \mu$-filtered, oxygenated seawater is between $10 \mathrm{~min}$ and $1 \mathrm{~h}$ (Bella et al., 1972). The high sulphide concentrations in the sediment (Fig. 5) and water column (Fig. 6) of the upper L'Etang are an important factor in maintaining this ecosystem in an anoxic condition. Sulphide is an extremely toxic compound (Sax, 1974) and concentrations as low as $0.075 \mathrm{mg} / 1$ at pH 7.6 to 8.0 are harmful to certain fish (Colby \& Smith, 1967); there are no eukaryotic organisms in the upper L'Etang ecosystem.

The sulphate-reducing bacteria can utilize only a limited range of organic compounds as their source of carbon and energy, viz, lactate, pyruvate, malate and formate (LeGall \& Postgate, 1973). These compounds are not imported into the system with the pulp mill effluent, it is therefore proposed that the nutritional requirements of the sulphate-reducing bacteria in the sediment are the metabolic by-products of either the anaerobic bacteria degrading cellulose or the non-cellulolytic heterotrophic anaerobic bateria associated with this process. Tezuka (1966) demonstrated a nutritional commensalism between sulphate-reducing bacteria and other heterotrophic bacteria.

\section{EFFECT OF PULP FIBRE ON THE SEDIMENT}

Model ecosystems (Fig. 7) were used by Poole et al. (1976b) to determine the effect of pulp fibre on the development of an anoxic sediment with a high sulphide concentration. In these experiments sediment from the upper L'Etang, or from an

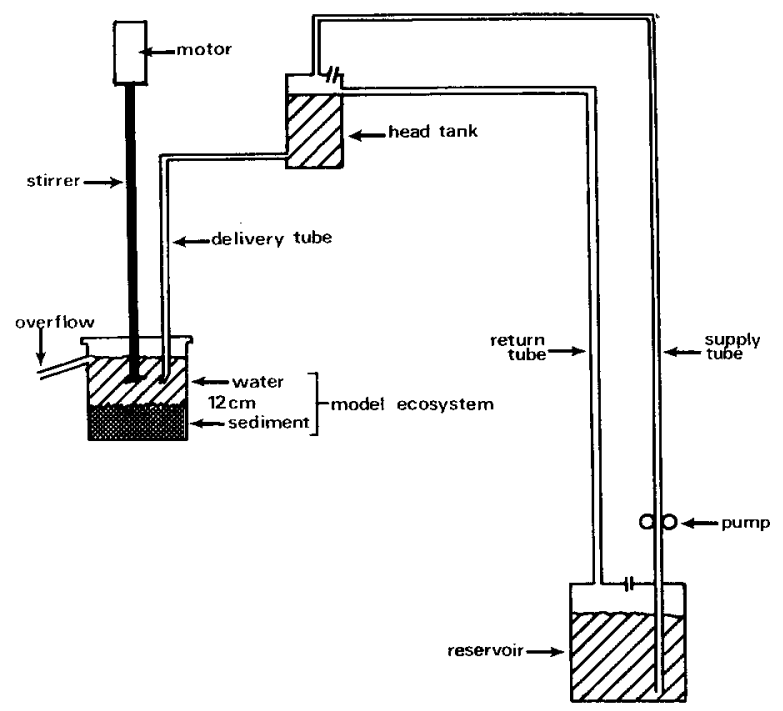

Fig. 7: Diagram of model ecosystem

unpolluted estuary, mixed with various concentrations of washed pulp fibre from Lake Utopia Mill, were placed in the model. Filtered seawater with a dissolved oxygen concentration of $8 \mathrm{mg} / 1$ and a negligible B.O.D. was passed over the sediment 
at a flow-rate equivalent to a retention time of 13,24 or $44 \mathrm{~h}$. The sequential chemical and microbiological changes were monitored at 2 day intervals over a 67 day period.

The results (Table 1) show that the upper L'Etang sediment exerted a considerable oxygen demand on, and released large quantities of sulphide into, the overlying water column. The addition of pulp fibre to a sediment caused an increase in both oxygen demand and sulphide concentration, with a resulting fall in the redox potential (the redox potential is a useful operational parameter for describing the ratio of oxidized to reduced forms within a system).

The rate of degradation of pulp fibre within the sediment, contained in the model ecosystems, was also determined using the nylon litter-bag technique (Hofsten \& Edberg, 1972). The rate was considerably reduced in those sediments with a high sulphide concentration and a low redox potential (Table 1). This reduction in cellulose degradation may be a result of the toxicity of sulphide towards the cellulolytic bacteria.

\section{SEASONAL VARIATIONS IN THE BACTERIAL COMMUNITY OF AN ESTUARINE SEDIMENT}

In the sediment of the Don estuary there is a relationship between the levels of total sulphide and the numbers of sulphate-reducing bacteria. The levels of sulphide and the numbers of sulphate-reducing bacteria were highest in the spring and early winter (Fig. 8), but during the summer there is a marked decrease, this is the period when the sulphide smell of the Don is most noticeable. This period of smell corresponds with the maximum summer temperatures and a marked decrease in the dissolved oxygen concentration of the water column.

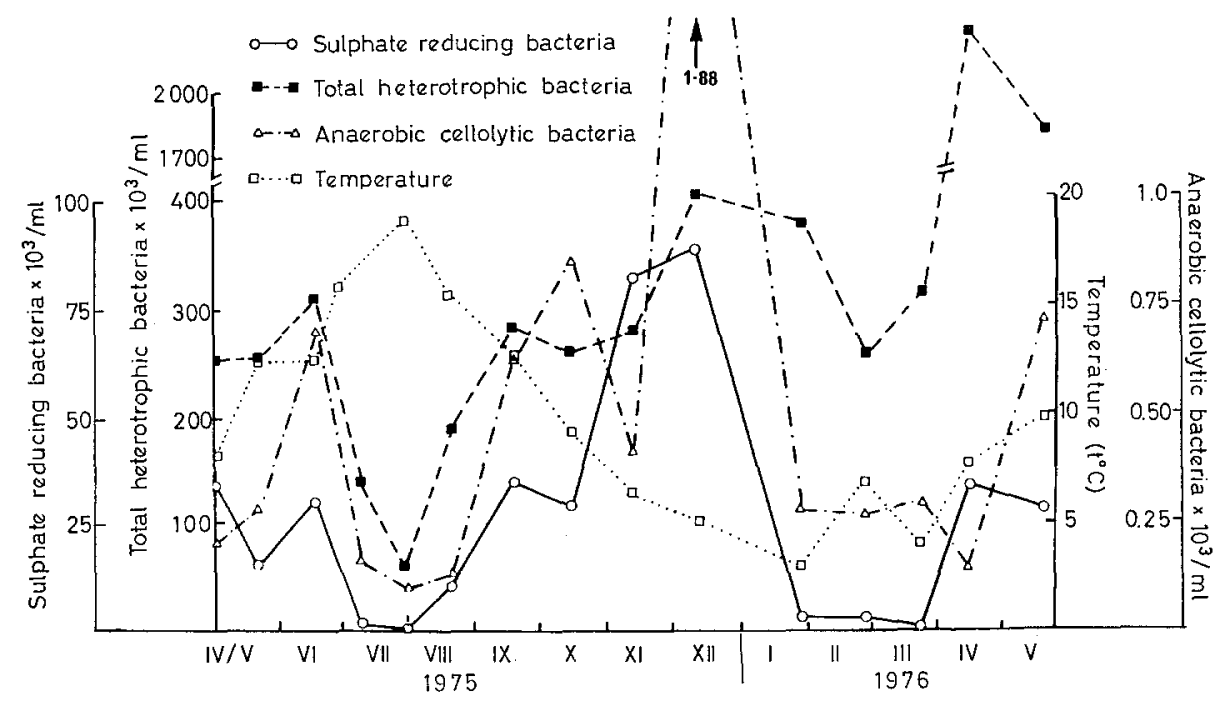

Fig. 8: Seasonal variations in temperature and of selected bacterial populations at a depth of $5 \mathrm{~cm}$ in the sediment of Don estuary at Station $\mathrm{C}$ 
Reaction of estuarine ecosystems

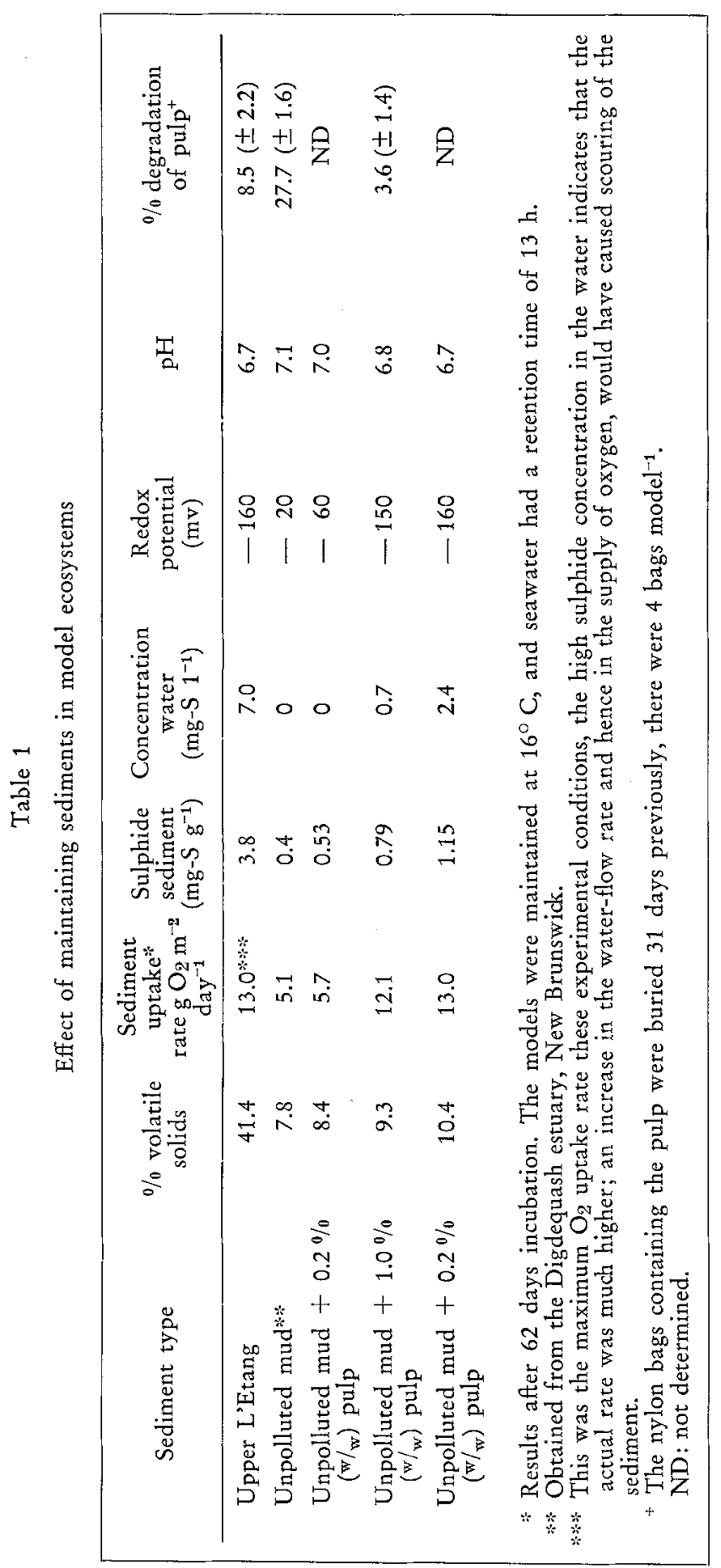


Parkes \& Poole (1976) presented a hypothesis to explain the decrease in bacterial numbers and the release of sulphide from a sediment, once all the available iron has been removed during the summer. The sulphide released from the sediment in the summer is the result of previous bacterial activity during the "spring bloom". The release of this pre-formed sulphide is probably related to the marked increase in sediment temperature, which would result in a decrease in the solubility of the sulphide and hence facilitate its release into the water column and atmosphere. Sulphide is toxic to prokaryotic as well as eukaryotic organisms and this toxicity would explain the drop in bacterial numbers after the "spring bloom".

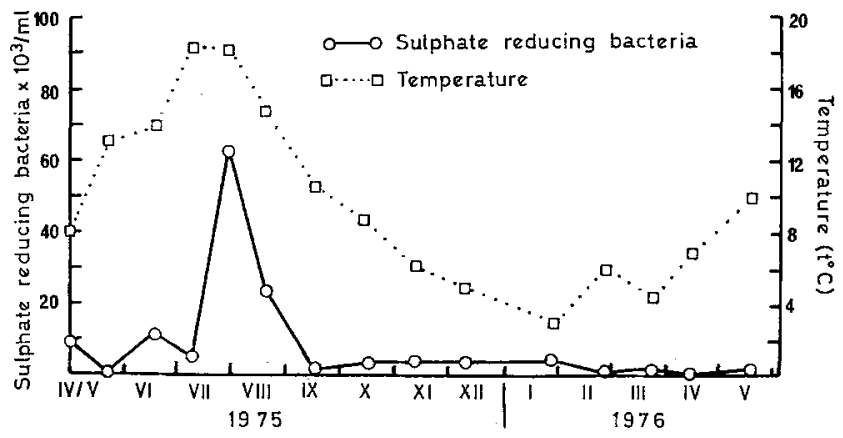

Fig. 9: Seasonal variation in temperature and sulphate-reducing bacteria at a depth of $5 \mathrm{~cm}$ in the sediment of Don estuary at Station A

Several authors have observed inhibition of bacterial growth by sulphide (heterotrophic bacteria, Sorokin, 1970; methanogenic bacteria, Cappenberg, 1974; sulphate-reducing bacteria, Brown et al., 1973). During winter the sulphate-reducing bacteria appear to tolerate a higher level of sulphide than in summer (Fig. 8); Saleh et al. (1964) commented that temperature might modify the toxicity of sulphide. In late summer, when much of the sulphide has been released, the gradual decrease in temperature would result in an increase in the amount of sulphide which the sediment can hold, a decrease in sulphide toxicity, and consequently an increase also in bacterial numbers. This increase in numbers will continue until a new toxic threshold of sulphide concentration is reached, or until bacterial activity is inhibited by the low winter temperatures.

Superimposed on this temperature effect, sulphide production will also be modified by the concentration of sulphate available as terminal electron acceptor. Different patterns of bacterial activity and sulphide production are exhibited at Stations $A$ and $C$ in the Don estuary. Station A is predominantly freshwater, while $C$ is seawater. A brief period of saltwater encroachment at Station A during the summer causes an increase in bacterial activity (Fig. 9) by supplying excess sulphate, which is probably limiting throughout the rest of the year. The rate of bacterial sulphate-reduction is independent of sulphate concentration when the concentration is $>10 \mathrm{mM}$ (Goldhaber \& Kaplan, 1975). 


\section{CONCLUSIONS}

In both the upper L'Etang and Don estuaries the discharge of pulp or paper mill effluent has resulted in the development of anoxic systems. The microbial degradation of the organic components of the effluent imposes a large oxygen demand on the system, while the supply of oxygen is limited by the restricted tidal exchange and, in addition, the presence on lignosulphonates in the upper L'Etang prevents green plant photosythesis.

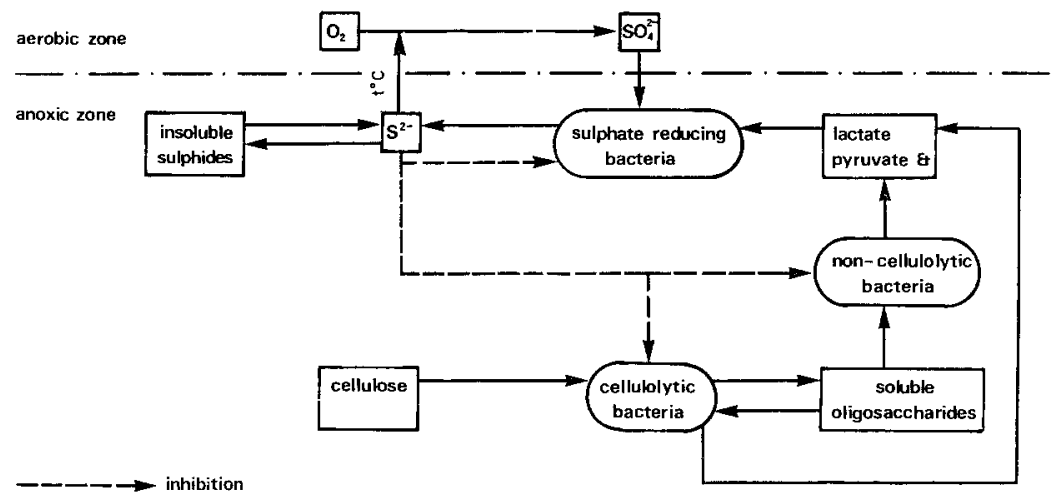

Fig. 10: Summary of proposed relationships between sulphate-reducing and cellulolytic bacteria in the sediment

The activities of certain bacterial populations within the sediment play an important role in the development and maintenance of anoxic conditions. The addition of cellulose, in the form of pulp fibre, to the sediment results, via nutritional commensalism with anaerobic heterotrophic bacteria, in an increase in the activities of the sulphate-reducing bacteria and hence an increase in their metabolic by-product sulphide. This sulphide may exert an inhibitory effect on the bacterial populations in the sediment; it may, therefore, be a major factor in controlling bacterial activity and the capacity of the ecosystem to cope with the effluent. Temperature may modify this toxic effect and be an important factor in controlling the release of sulphide into the overlying water column and atmosphere. The relatively rapid chemical oxidation of sulphide in oxygenated seawater places an additional oxygen demand on the system. The proposed relationship between the cellulolytic and sulphate reducing bacteria within the sediment is shown diagrammatically in Figure 10.

Bacterial sulphate reduction is the penultimate stage of gross organic pollution, the final stage is methanogenesis. The development of anoxic conditions and the appearance of sulphide is a disaster for the eukaryotic organisms, whose death may in turn augment the gross pollution. Detection of sulphate reduction is, as Postgate (1973) said remarkably easy; cure is, however, rare and expensive, while prevention requires foresight.

Acknowledgements. Much of the research in this paper was supported by funds from the Carnegie Trust for the Universities of Scotland; Department of the Environment, Canada; C. Davidson and Sons; North East River Purification Board and Wiggins Teape Ltd. The authors wish to thank the many "volunteers" for their assistance in sampling. 


\section{LITERATURE CITED}

Bella, D. A., Ramm, A. E. \& Peterson, P. E., 1972. Effects of tidal flats on estuarine water quality. J. Wat. Pollut. Control Fed. 44, 541-556.

Brown, D. E., Groves, G. R. \& Miller, J. D. A., 1973. pH and Eh control of cultures of sulphate-reducing bacteria. J. appl. Chem. Biotechnol. 23, 141-149.

Cappenberg, T. E., 1974. Interrelations between sulfate-reducing and methane-producing bacteria in bottom deposit, of a freshwater lake. 1. Field observations. Antonie van Leeuwenhoek 40, 285-295.

Colby, P. I. \& Smith, L. L., 1967. Survival of walleye eggs and fry and paper fibre sludge deposits in Rainy River, Minnesota. Trans. Am. Fish. Soc. 96, 278-296.

Goldhaber, M. B. \& Kaplan, I. R., 1974. The sulphur cycle. In: The sea. Ed. by E. D. Goldberg. Wiley, London, 5, 569-655.

- - 1975. Controls and consequences of sulphate reduction rates in recent marine sediments. Soil Sci. 119, 42-55.

Hofsten, B. von \& Edberg, N., 1972. Estimating the rate of degradation of cellulose fibres in water. Oikos 23, 29-34.

Holm-Hansen, O., 1973. The use of ATP determinations in ecological studies. Bull. ecol. Res. Commn (Stockholm) 17, 215-222.

Kristmanson, D. D., Wildish, D. J. \& Poole, N. J., 1976. Mixing of pulp mill effluent in the upper L'Etang. Manuscr. Rep. Ser. Fish. Res. Bd Can. (In press.)

LeGall, J. \& Postgate, J. R., 1973. The physiology of sulphate-reducing bacteria. Adv. microb. Physiol. 10, 82-125.

Parker, R. R. \& Sibert, J., 1973. Effect of pulpmill effluent on dissolved oxygen in a stratified estuary. 1. Empirical observations. Wat. Res. 7, 503-514.

- - 1976. Response of phytoplankton to renewed solar radiation in a stratified inlet. Wat. Res. 10, 123-128.

Parkes, R. J. \& Poole, N. J., 1976. The seasonal variations of selected bacterial populations in estuarine sediments. J. appl. Bact. (In press.)

Pearson, T. H. \& Rosenberg, R., 1976. A comparative study of the effects on the marine environment of wastes from cellulose industries in Scotland and Sweden. Ambio 5, 77-79.

Poole, N. J., Wildish, D. J. \& Lister, N., 1976a. Effects of a neutral-sulphite, pulp mill effluent on some chemical and biological parameters in the L'Etang Inlet, New Brunswick. L'Etang Inlet Survey III. Manuscr. Rep. Ser. Fish. Res. Bd Can. (In press.)

- $-1976 \mathrm{~b}$. The use of microecosystem models to investigate pollution of the estuarine ecosystem by pulp mill efffuent. Manuscr. Rep. Ser. Fish. Res. Bd Can. (In press.)

Postgate, J. R., 1973. Sulphate reduction in pollution processes. Bull. ecol. Res. Commn (Stockholm) 17, 477.

Ramm, A. E. \& Bella, D. A., 1974. Sulfide production in anaerobic microcosms. Limnol. Oceanogr. 19, 110-118.

Saleh, A. M., Macpherson, R. \& Miller, J. D. A., 1964. The effect of inhibitors on sulphatereducing bacteria: a compilation. J. appl. Bact. 27, 281-293.

Sax, N. I., 1974. Industrial pollution. Van Nostrand - Reinhold, New York, 702 pp.

Sorokin, Y. I., 1970. Interrelations between sulphur and carbon turnover in leromictic lakes. Arch. Hydrobiol. 66, 391-446.

Tezuka, Y., 1966. A commensalism between the sulphate-reducing bacterium Desulfovibrio desulfuricans and other heterotrophic bacteria. Bot. Mag. Tokyo, 79, 174-178.

Wildish, D. J., Poole, N. J. \& Kristmanson, D. D., 1976. The effect of anaerobiosis on measurement of sulfite pulp mill effluent concentration by $\mathrm{U}$. V. spectrophotometry. Bull. environm. Contam. Toxicol. 16, 208-213.

First author's address: Dr. N. J. Poole

Department of Microbiology

Marischal College

University of Aberdeen

Aberdeen AB9 1AS

Scotland 